\title{
Organisational Culture, Stress and Commitment: A Study of Managers of Pharmaceutical Industry in Himachal Pradesh
}

\author{
Om Parkash Monga1 ${ }^{*}$, Anubhuti Monga², Varun Mahajan³, Anubhav Monga ${ }^{4}$ \\ ${ }^{1}$ Faculty of Management Sciences and Liberal Arts, Shoolini University of Biotechnology and Management \\ Sciences, Solan, India \\ ${ }^{2}$ Anubhuti Monga, Software Engineer \& HR Professional, Solan, India \\ ${ }^{3}$ Varun Mahajan, Mentor Graphics INDIA Private Limited, Noida, India \\ ${ }^{4}$ Anubhav Monga, HCL America Inc., Cary, USA \\ Email: opmonga2001@yahoo.com, anubhuti07@gmail.com, varunmahajan06@gmail.com, \\ anubhavmonga@gmail.com
}

Received 28 September 2015; accepted 13 October 2015; published 19 October 2015

Copyright (C) 2015 by authors and OALib.

This work is licensed under the Creative Commons Attribution International License (CC BY). http://creativecommons.org/licenses/by/4.0/

(c) (i) Open Access

\begin{abstract}
The primary focus of this study was to understand the workplace stress by exploring the effects of organisational culture and stress on employee commitment. The attempt was to bridge the gap among organisational culture, workplace stress and employee commitment. Although the concepts of organizational culture and stress have been well researched upon in the past, a few studies provide detailed insights into the interplay among the concepts of organisational culture, workplace stress and commitment. This investigation therefore understood this interplay within pharmaceutical industries located in two districts: Solan and Sirmour in the state of Himachal Pradesh. The questionnaire was used to gather data from the staff through survey by using a questionnaire. The analysis of statistical results interestingly reveals that the pharmaceutical industry exhibits a hierarchical culture that is supportive. The staffs have too much work to do with less time for the accomplishment. The assessment of employee commitment further revealed that the employees were pleased with the reward system of the industry. The relationship among organisational culture, stress and commitment was significant. The study suggests that there is a need to change the work load policy, reduce the stress levels of the employees and improve the organisational commitment of the employees.
\end{abstract}

${ }^{*}$ Corresponding author.

How to cite this paper: Monga, O.P., Monga, A., Mahajan, V. and Monga, A. (2015) Organisational Culture, Stress and Commitment: A Study of Managers of Pharmaceutical Industry in Himachal Pradesh. Open Access Library Journal, 2: e1941. http://dx.doi.org/10.4236/oalib.1101941 


\title{
Keywords
}

\section{Employee Commitment, Workplace Stress, Organisational Culture, Competing Values Framework and Hierarchical Structure}

\author{
Subject Area: Human Resource Management
}

\section{Introduction}

Organisational culture and stress are two concepts that have been widely recognised in the literature. However, not much work has been done on how culture and stress can impact commitment [1]. Organisational culture is one of the dominant concepts which may have bearing on the organisational commitment of employees [2]. It outlines the norms of organisational behaviours in any given organisation. It also explains the basic assumptions of different organisations which must be inculcated among organisational members that will form the basis of their behaviours and attitudes, including their commitment to organisations. As organisations comprised of people, they have become part of its culture. Since these people interact in the organisation, the basic assumptions they hold and nurture will develop the culture of an organisation [3].

Organisational culture as an antecedent of organisational commitment underlies the processes through which people identify themselves with different events in their environment and how they are shaped by them in determining their commitments and purposes in life [1]. Hence, integrative organisational culture that encourages "peoples first" will win the commitment of its employees. The human resource often accounts for a great cost in organisations and any further increase in this cost may adversely tell upon the profitability and viability of the organisation. The job stress continues to be a major concern of everyday life which may lead to substantial costs to individuals. Though the pervasiveness of stress has been perceived as an integral part of life, it can be both pleasant and unpleasant, depending on the adaptive capacity of individuals [4]. A peep into the literature revealed that workplace stress converged around two areas of organisational functions and culture such as organisation as task environment and organisation as development environment [5] and any organisational poor performance in these key areas is likely to promote increased levels of stress [2]. In this regard, organisational value system may have a profound effect on the preference and attitudes of workers and organisational culture may therefore elicit the kind of relationships among employees that can promote their commitment and performance [6] which may otherwise result in stress. A stressor is thus understood as any event, situation or cognition that may evoke negative emotion in an individual [7].

\section{Concepts}

Available literature provides vital insight into the concepts of organisational culture, workplace stress and employee commitment, and the mechanism through which these are intricately connected to each other.

\subsection{Organisational Culture}

Culture in an organisation is perceived as a great force and social glue that holds organisational members together, which is then transmitted to incoming employees that determines the performance of the organisation as well as the commitment of the employees [3]. In contrast to this, Martins [8] talked about integration, differentiation and fragmented cultures the dynamics of which is required to determine the commitment of employees rather than group or integrative culture alone.

Viewing beyond Schein's proposition, the commitment of the employees in organisations might only be enhanced if the cultural values are congruent with the desired belief and values of the employees [9]. The literature points out that the value incongruence to be associated with lower job related attitudes with high endorsement value congruence to be related to higher job related attitudes [5] [10]. Thus, that organisational culture is a set of shared values that influence the behaviour of organisational members; such behavioural influence can only exist because individuals behave in ways that are consistent with their values [5]. Hence, it is expected that organisational culture should create behavioural expectancies that would make employees be- 
have in ways that are consistent with their cultural expectations and the existence of this relationship between culture and behaviour has been considered to be theoretical basis for the assertion that culture influences commitment [11].

Moreover, it was argued by Ogbonna [12] that the shared and strongly held values by employees in an organisation will enable the management to predict employee attitudes and reactions to certain strategic option thus minimizing the extent of undesired consequences. It thus behoves on organisations to identify the prevailing values of employee, in order to forestall any negative consequences that might affect the commitment of its employees. Consequently, the various definitions of organisational culture as a complex set of values, beliefs and assumption that define the way organisational conducts its business ,and also as basic assumptions about how things are shared by group of people which determines their perceptions, thoughts, feelings and their overt behaviours [3] [13]. A shared meaning of values held by organisational members that distinguish one organisation from the other [14] however, suggest that different organisations could be regarded as having different cultures that affect or influence the attitudes, behaviours and commitment of their employees [15]. Hence, one can be realise that organizational culture that focuses on productivity and achievement and other behaviours such as change adaptation in order to grow the organization as well as strict adherence to guidelines in order to regulate the behaviours of employees to the detriment of employee values in the organization may incur a low commitment of organizational members which may warrant negative consequences on both the employees and the organization [8].

Lok and Crawford [16] examined three dimensions of culture, such as, innovative, supportive and bureaucratic in their study of the relationship between organisational culture, sub-culture and commitment emphasize strong norms for obligation, internalization and identification are likely to generate high levels of normative and affective commitments. The activities of sub-cultural groupings predict another dimension to employee commitment in organisations. It should therefore be perceived that a number of factors determine organisational effectiveness and employee commitment and thus makes it arduous to establish a relationship between organisational culture and overall organisational effectiveness and commitment Therefore, a mis-match between the culture of an organisation and the embedded cultural assumptions might be costly to the maximum commitment and performance of employees [5]. In an empirical study of Job Satisfaction of employees of ICICI Bank in Himachal Pradesh, India, it was found that elements of organizational culture, such as, inter-personal relationship, communication, attitude of superiors, working conditions and team work have more bearing in determining job satisfaction of employees. They pointed out that democratic organisational culture inculcates positive values among employees which leads to more job satisfaction [17]. In another study of managers of pharmaceutical companies it was found that demographic variables are less relevant in determining the job performance and job satisfaction, whereas as the organizational culture plays an important role in determining job performance and job satisfaction. This means job satisfaction and job performance may be regarded as crucial in determining job stress of employees [13] [18].

It is evident from the above conceptual description that the organizational culture includes multiple and invisible aspects. Understanding relationship between organizational culture, job commitment and stress demands to include all those aspects which comprise it, which is difficult to realize. However, for the present study, the organizational culture was understood as encompassing beliefs and values which employees nurture toward activities of an organization, such as, innovation, inter-personal relationship and support, sharing, attitude of superiors, teamwork, stability, structure and achievement orientation.

\subsection{Job Stress}

The phenomenon of job stress has acquired global dimensions that has implications for economies and which range from low commitment of employees to their jobs, lost productivity, stress related suits and health care expenses which from individual perspectives manifested in an undesirable physiological and psychological conditions such as morbidity, mortality, depression and anxiety [19] [20]. Consequently, there is increase demand to human resource practitioners to promote employee physical and psychological health, job related attitudes such as commitment and performance [21].

Surprisingly, the focus has always been on the assessment of individual capabilities and their resources to cope with these consequences [21] rather than tackling the root cause of the problem which derive from the pre- 
vailing cultures of the organisations. Therefore, if the culture of organisations define the way employees think, interact and do things, it follows thence that the culture of an organisation might be the antecedents of job stress that negatively impact the health of the employees, their productivity levels and commitments to the organisation. As a result, the concepts of organisational culture, job stress and employees commitment are interwoven and dynamic variables that requires the utmost attention of human development managers. This needs holistic analysis in order to design a probable work environment that evokes the commitment of employees to their jobs and decreases level of their stress. In addition to this, other interest has been on the work place characteristics that are associated with employee strain and low commitment levels to their jobs. Perusal of literature on job stress revealed role stressors and the specific task being performed by the employees, such as, role conflict, role ambiguity and role overload related to emotional exhaustion, depersonalization, job commitment and turnover [22].

Similarly, cultural influence on role conflict result to role stress, and this was experienced by the local Japanese staff inform of role overload and role incompetence. This occurred because the Japanese expatriate feel more comfortable with LJ staff that have understood the Japanese style work practices than with the Non-Japanese local Staff in Australia [23]. Concomitantly therefore, this underscores the importance of organisational culture as antecedents of job stress, Job Commitment and Job Performance in the work place [24]. It thus can be understood that different cultural work contexts impact the level of stress and the level of job commitment in organisations.

\subsection{Organisational Commitment}

The commitment of the employees is a continued concern for the organisation well-being, success and development. This has led employers to focus on the development of their human capital to deliver more with fewer investments [1]. Therefore, if employees commitment is their degree of identification with the missions and goals of the organisation and the willingness to remain in it, it follows therefore that the employers should embark on activities that will enable them retain the skilled, talented and committed workforce [25]. In literature, four general antecedents such as personal characteristics, job characteristics, Work experience and Role related characteristics have been identified [26]. However, one also comes across with conflicting findings and results in respect to organisational commitment and job stress analysis [27]. Therefore, perspectives amongst us have realised organisational culture is vital in the analysis of commitment and ensures the potential of enhancing employee commitment. The study on the correlates of organisational culture, job stress and employee commitment showed that organisational culture statistically influence job stress and found a negative correlation between job stress and job commitment [28].

In this background and from prospective point of view, the analysis and understanding of the dynamics of organisational culture, job stress and employee commitment variables is warranted to explain the impact of one on another and vice-versa.

\section{Theoretical Framework}

There are number of theoretical explanations of organisational culture available in literature. But this study adopted the Competing Values Framework [CVF] to understand the phenomenon under investigation. This framework has the text of validity conducted on its relevance in explaining and assessing culture where the interest is on relating it to organisational commitment. The CVF was proposed by Zammuto and Krakower [29] to evaluate organisational culture from two dimensions i.e. structure and focus. The structural dimension expands from the control on one end to the flexibility on the other end. It shows the variations of organisations that strive for consistent patterns of behaviours and those that attempt to allow their employees to fashion out their own behavioural pattern; the focus dimension ranges from external focus with emphasis on the capacity of the organisation to perform optimally in its environment and an internal focus that emphasizes internal factors of the organisation such as employee commitment and satisfaction [10]. The CVF as depicted by Quinn and Spreitzer [30] includes five important aspects: the Group Culture, the Developmental Culture, the Rational Culture, the Hierarchical Culture and the Balanced Culture.

The Competing Values Framework 


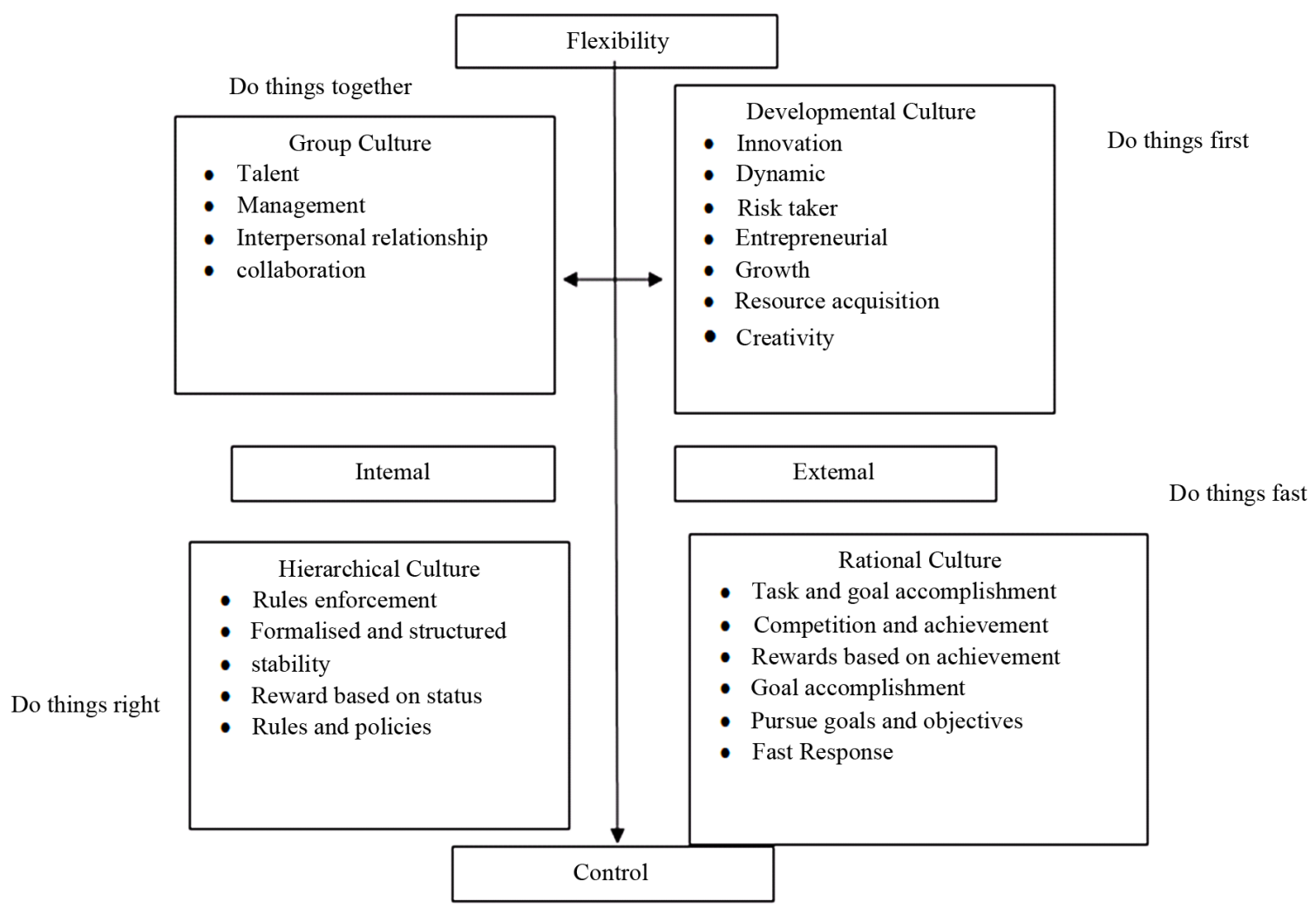

Source: Parker and Brandley (2000, p. 128).

The Group Culture is characterized by high flexibility with an internal focus. The culture here emphasizes the importance of group dynamics that explains itself in cohesiveness, participatory decision-making and considerable support among employees of the group. The Developmental Culture is externally focused with emphasis on flexibility; and its orientation is that of change and adaption. The Rational Culture is externally focused control with attainment of goal as seen significant so as to instil control on the employee actions and direct their behaviours towards external environment. The culture gives premium to productivity, competition and achievement and fast response in accomplishing tasks. The Hierarchical Culture emphasizes internally-focused control. There is an emphasis on coordination and uniformity aiming at internal efficiency. The formalized structure and strict adherence to rules and policies tend to regulate employee behaviours and equally provide job security to the employees. The Balanced Culture combines the attributes and values of each of the CVF. This concept of cultural balance within the CVF was introduced by Quinn. in order to equip the organisations towards managing the advantage of environmental shifts [31].

The importance of work in lives of individuals is a testimony to the fact that any event in an organisation that could result to negative emotions may have serious bearing on the organisational commitment. In the context of a few researches that have demonstratively linked organisational culture and stress to employee commitment in organisations, this study therefore intends to investigate two pertinent questions: first, is there a significant relationship between organisational culture and job stress on employee commitment and performance? and second, to what extent the interactions between organisational culture and job stress affect organisational commitment of employees?

\section{Objectives}

It can be observed from the findings of research studies on culture and stress that organisational culture within an organisation can lead to stress among the members of the organisation and in turn can provoke both affective and behavioural responses. In this backdrop, this study examined the interface between organisation culture and stress and the effect of such interactions on the organisational commitment of the employees. 
The objectives of this study were:

1) To examine the relationship between organisational culture and job stress. and its effect on job commitment;

2) To understand the extent of effect of the interactions between organisational culture and job stress on organisational commitment of employees.

\section{Methods}

There are 362 large, medium and small pharmaceutical companies spread over seven districts in the state of Himachal Pradesh. Out of this, 312 are situated in two districts namely, Solan having 262 and Sirmour 64 units. In order to reduce variance and to have almost homogenous group, the sample for this study was drawn from 15 large pharmaceutical companies located in Solan and Sirmour districts of Himachal Pradesh. There were 382 managers working in these companies. All such managers were included in this study. The relevant data for the assessment of the organisational culture, the workplace stress and employee commitment was collected by the use of questionnaire. The elements of organisational culture were measured by using instruments developed by Zammuto and Krakower [29]; the workplace stress was assessed with the help of the instrument developed by Chang [19]; and to measure commitment instrument developed by Meyer, and Allen was used [32]. The questionnaires were sent to all the 382 managers. Out of this 300 questionnaire were received back. Analysis was carried out using percentage, mean, standard deviation and correlation.

\section{Findings}

\subsection{Perception of Managers about Organisational Culture}

This part gives the perception of 300 managers of pharmaceutical companies who returned the questionnaire complete in all respects. The perception is about the organisational culture which is in existence in their industries. Their responses on ten dimensions of organizational culture were analysed. The findings converged in the belief of the managers and their agreement with the elements that stand for the different types of organisational culture that is in existence in their organisation derived from Competing Value Framework (CVF) discussed above.

- OCU1, OCU2 and OCU3 represented rational culture;

- OCU4, OCU5 and OCU6 represented group culture;

- OCU7 and OCU8 represented developmental culture;

- OCU9 and OCU10 represented Hierarchical culture.

The statistical findings of the strength of agreement plus the ranking of the types of organisational culture that existed at the pharmaceutical companies, is presented in Table 1.

It becomes evident from the statistical analysis in Table 1 that there was consensus in the department on how the job is to be completed. The OCU-2, which had to follow a bureaucratic process OCU-10, and that the department was highly formalized OCU-9. These dimensions had mean scores of 3.96, 3.92 and 3.88 respectively. Items OCU-7 and OCU-8 have the weakest agreement meaning that the department is dynamic and Entrepreneurial. Two dimensions i.e. 0CU-7 and OCU-8 indicate the willingness of the employees in the industry to take risks. The mean scores for OCU-7 and OCU-8 were $\mathrm{M}=3.22$ and $\mathrm{M}=3.15$, respectively. It can be concluded that the culture of the pharmaceutical industry is bureaucratic and therefore operates in a hierarchical fashion, indicating the prevalence of hierarchical culture.

Statistical Analysis of Job Stress in Table 2 indicates relationship between the existence of stress about their Job and the workplace. The data show the strength of managers in respect to the existence of stress in this study and indicate that the largest agreement among the respondents is on JS10 - I have too many assignments to complete at a time. The mean score was $\mathrm{M}=3.33$ and the standard deviation $\mathrm{SD}=1.27$ which reflects that the departmental culture was unsympathetic.

\subsection{Perception of Job Commitment}

The data spread in Table 3 reflect that the dimensions of job commitment i.e. items JC- 8 and JC-4 expressed the weakest agreement in respect of welfare packages and the rewarding systems. The mean scores were $\mathrm{M}=3.20$ and $\mathrm{M}=2.92$ respectively, showing that the concern for workers' welfare was negligible. The employees were dissatisfied with the award of welfare packages as well as the organisation's rewarding system. 
Table 1. Perception of organizational culture.

\begin{tabular}{|c|c|c|c|c|c|c|c|c|c|}
\hline \multirow[t]{2}{*}{ Sr. No. } & \multirow[t]{2}{*}{$\mathbf{Q}$} & \multirow[t]{2}{*}{ OCU1 } & \multirow[t]{2}{*}{ OCU items OCU1 } & \multicolumn{5}{|c|}{ Frequency } & \multirow[t]{2}{*}{ Mean SD } \\
\hline & & & & 1 & 2 & 3 & 4 & 5 & \\
\hline 1 & 2 & OCU2 & $\begin{array}{l}\text { The concern of the department is to get the } \\
\text { job accomplished }\end{array}$ & $\begin{array}{l}10 \\
3.33\end{array}$ & $\begin{array}{l}18 \\
6.00\end{array}$ & $\begin{array}{l}60 \\
20.00\end{array}$ & $\begin{array}{l}172 \\
57.33\end{array}$ & $\begin{array}{l}40 \\
13.33\end{array}$ & $\begin{array}{l}3.96 \\
0.81\end{array}$ \\
\hline 2 & 10 & OCU10 & $\begin{array}{l}\text { The department is governed by bureaucratic } \\
\text { rules }\end{array}$ & $\begin{array}{l}11 \\
3.67\end{array}$ & $\begin{array}{l}22 \\
7.33\end{array}$ & $\begin{array}{l}66 \\
22.00\end{array}$ & $\begin{array}{l}152 \\
50.67\end{array}$ & $\begin{array}{l}49 \\
16.33\end{array}$ & $\begin{array}{l}3.92 \\
0.91\end{array}$ \\
\hline 3 & 9 & OCU9 & $\begin{array}{l}\text { My department is formalized and structured } \\
\text { place }\end{array}$ & $\begin{array}{l}20 \\
6.67\end{array}$ & $\begin{array}{l}16 \\
5.33\end{array}$ & $\begin{array}{l}53 \\
17.67\end{array}$ & $\begin{array}{l}171 \\
57.00\end{array}$ & $\begin{array}{l}40 \\
13.33\end{array}$ & $\begin{array}{l}3.88 \\
0.99\end{array}$ \\
\hline 4 & 4 & OCU4 & The department is personalised & $\begin{array}{l}11 \\
3.67\end{array}$ & $\begin{array}{l}19 \\
6.33\end{array}$ & $\begin{array}{l}94 \\
31.33\end{array}$ & $\begin{array}{l}125 \\
41.67\end{array}$ & $\begin{array}{l}51 \\
17.00\end{array}$ & $\begin{array}{l}3.84 \\
0.94\end{array}$ \\
\hline 5 & 1 & OCU1 & The department is production oriented & $\begin{array}{l}20 \\
6.67\end{array}$ & $\begin{array}{l}33 \\
11.00\end{array}$ & $\begin{array}{l}63 \\
21.00\end{array}$ & $\begin{array}{l}137 \\
45.67\end{array}$ & $\begin{array}{l}47 \\
15.67\end{array}$ & $\begin{array}{l}3.73 \\
1.14\end{array}$ \\
\hline 6 & 5 & OCU5 & The department is extended family & $\begin{array}{l}12 \\
4.00\end{array}$ & $\begin{array}{l}58 \\
19.33\end{array}$ & $\begin{array}{l}65 \\
21.67\end{array}$ & $\begin{array}{l}112 \\
37.33\end{array}$ & $\begin{array}{l}53 \\
17.67\end{array}$ & $\begin{array}{l}3.64 \\
1.15\end{array}$ \\
\hline 7 & 6 & OCU6 & $\begin{array}{l}\text { The departmental staff share much about } \\
\text { themselves }\end{array}$ & $\begin{array}{l}10 \\
3.33\end{array}$ & $\begin{array}{l}49 \\
16.33\end{array}$ & $\begin{array}{l}76 \\
25.33\end{array}$ & $\begin{array}{l}128 \\
42.67\end{array}$ & $\begin{array}{l}37 \\
12.33\end{array}$ & $\begin{array}{l}3.63 \\
1.03\end{array}$ \\
\hline 8 & 3 & OCU3 & The department is involved personally & $\begin{array}{l}11 \\
3.67\end{array}$ & $\begin{array}{l}39 \\
13.00\end{array}$ & $\begin{array}{l}114 \\
38.00\end{array}$ & $\begin{array}{l}103 \\
34.33\end{array}$ & $\begin{array}{l}33 \\
11.00\end{array}$ & $\begin{array}{l}3.53 \\
0.98\end{array}$ \\
\hline 9 & 7 & OCU7 & The department is dynamic & $\begin{array}{l}26 \\
8.67\end{array}$ & $\begin{array}{l}65 \\
21.67\end{array}$ & $\begin{array}{l}92 \\
30.67\end{array}$ & $\begin{array}{l}88 \\
29.33\end{array}$ & $\begin{array}{l}29 \\
9.67\end{array}$ & $\begin{array}{l}3.22 \\
1.14\end{array}$ \\
\hline 10 & 8 & OCU8 & The department is a risk taker & $\begin{array}{l}22 \\
7.33\end{array}$ & $\begin{array}{l}73 \\
24.33\end{array}$ & $\begin{array}{l}91 \\
30.33\end{array}$ & $\begin{array}{l}73 \\
24.33\end{array}$ & $\begin{array}{l}41 \\
13.67\end{array}$ & $\begin{array}{l}3.15 \\
1.13\end{array}$ \\
\hline
\end{tabular}

Note: $\mathrm{OCU}=$ Organizational Culture; Figures below frequencies indicate percentages.

Table 2. Perception of the job stress.

\begin{tabular}{|c|c|c|c|c|c|c|c|c|c|}
\hline \multirow[t]{2}{*}{ Sr. No. } & \multirow[t]{2}{*}{$\mathbf{Q}$} & \multirow[t]{2}{*}{ JSI } & \multirow[t]{2}{*}{ JS items [JSI] } & \multicolumn{5}{|c|}{ Frequency } & \multirow[t]{2}{*}{ Mean SD } \\
\hline & & & & 1 & 2 & 3 & 4 & 5 & \\
\hline 1 & 10 & JS10 & $\begin{array}{l}\text { I have too many assignments to complete at } \\
\text { a time }\end{array}$ & $\begin{array}{l}23 \\
7.67\end{array}$ & $\begin{array}{l}77 \\
25.67\end{array}$ & $\begin{array}{l}70 \\
23.33\end{array}$ & $\begin{array}{l}79 \\
26.33\end{array}$ & $\begin{array}{l}51 \\
17.00\end{array}$ & $\begin{array}{l}3.33 \\
1.27\end{array}$ \\
\hline 2 & 9 & JS9 & $\begin{array}{l}\text { Many assignments are given with limited } \\
\text { time to accomplish }\end{array}$ & $\begin{array}{l}37 \\
12.33\end{array}$ & $\begin{array}{l}76 \\
25.33\end{array}$ & $\begin{array}{l}35 \\
11.67\end{array}$ & $\begin{array}{l}99 \\
33.00\end{array}$ & $\begin{array}{l}53 \\
17.67\end{array}$ & $\begin{array}{l}3.32 \\
1.40\end{array}$ \\
\hline 3 & 6 & JS6 & $\begin{array}{l}\text { Many assignments are given without enough } \\
\text { material to accomplish them }\end{array}$ & $\begin{array}{l}43 \\
14.33\end{array}$ & $\begin{array}{l}124 \\
41.33\end{array}$ & $\begin{array}{l}24 \\
8.00\end{array}$ & $\begin{array}{l}72 \\
24.00\end{array}$ & $\begin{array}{l}37 \\
12.33\end{array}$ & $\begin{array}{l}2.84 \\
1.37\end{array}$ \\
\hline 4 & 2 & JS2 & There is no clear work orientation & $\begin{array}{l}48 \\
16.00\end{array}$ & $\begin{array}{l}107 \\
35.67\end{array}$ & $\begin{array}{l}56 \\
18.67\end{array}$ & $\begin{array}{l}70 \\
23.33\end{array}$ & $\begin{array}{l}19 \\
6.33\end{array}$ & $\begin{array}{l}2.77 \\
1.21\end{array}$ \\
\hline 5 & 1 & JS1 & $\begin{array}{l}\text { Limited time was given for completion of } \\
\text { my work }\end{array}$ & $\begin{array}{l}57 \\
19.00\end{array}$ & $\begin{array}{l}109 \\
36.33\end{array}$ & $\begin{array}{l}46 \\
15.33\end{array}$ & $\begin{array}{l}61 \\
20.33\end{array}$ & $\begin{array}{l}27 \\
9.00\end{array}$ & $\begin{array}{l}2.62 \\
1.30\end{array}$ \\
\hline 6 & 8 & JS8 & $\begin{array}{l}\text { Assignments that are above my skills are } \\
\text { assigned }\end{array}$ & $\begin{array}{l}51 \\
17.00\end{array}$ & $\begin{array}{l}122 \\
40.67\end{array}$ & $\begin{array}{l}42 \\
14.00\end{array}$ & $\begin{array}{l}56 \\
18.67\end{array}$ & $\begin{array}{l}29 \\
9.67\end{array}$ & $\begin{array}{l}2.66 \\
1.29\end{array}$ \\
\hline 7 & 7 & JS7 & $\begin{array}{l}\text { Guidelines for accomplishment are often not } \\
\text { followed }\end{array}$ & $\begin{array}{l}57 \\
19.00\end{array}$ & $\begin{array}{l}119 \\
39.67\end{array}$ & $\begin{array}{l}37 \\
12.33\end{array}$ & $\begin{array}{l}53 \\
17.67\end{array}$ & $\begin{array}{l}34 \\
11.33\end{array}$ & $\begin{array}{l}2.35 \\
1.35\end{array}$ \\
\hline 8 & 4 & JS4 & Lack of social support by colleagues at work & $\begin{array}{l}69 \\
23.00\end{array}$ & $\begin{array}{l}125 \\
41.67\end{array}$ & $\begin{array}{l}29 \\
9.67\end{array}$ & $\begin{array}{l}40 \\
13.33\end{array}$ & $\begin{array}{l}37 \\
12.33\end{array}$ & $\begin{array}{l}2.50 \\
1.37\end{array}$ \\
\hline 9 & 5 & JS5 & Ambiguity in the nature of job role & $\begin{array}{l}72 \\
24.00\end{array}$ & $\begin{array}{l}122 \\
40.67\end{array}$ & $\begin{array}{l}30 \\
10.00\end{array}$ & $\begin{array}{l}52 \\
17.33\end{array}$ & $\begin{array}{l}24 \\
8.00\end{array}$ & $\begin{array}{l}2.44 \\
1.28\end{array}$ \\
\hline 10 & 3 & JS3 & $\begin{array}{l}\text { The goals and objectives of my job are } \\
\text { ambiguous }\end{array}$ & $\begin{array}{l}131 \\
43.67\end{array}$ & $\begin{array}{l}94 \\
31.33\end{array}$ & $\begin{array}{l}28 \\
9.33\end{array}$ & $\begin{array}{l}35 \\
11.67\end{array}$ & $\begin{array}{l}12 \\
4.00\end{array}$ & $\begin{array}{l}1.91 \\
1.10\end{array}$ \\
\hline
\end{tabular}

Note: JS = Job Stress; Figures below frequencies indicate percentages.

\subsection{Correlation between Organisational Culture, Workplace Stress and Job Commitment}

To investigate correlation between three domains i.e. Organisational Culture, Workplace Stress and Job Commitment, highest mean for organisational culture and work stress and the lowest mean for commitment were 
Table 3. Perception of commitment.

\begin{tabular}{|c|c|c|c|c|c|c|c|c|c|}
\hline \multirow[t]{2}{*}{ Sr. No. } & \multirow[t]{2}{*}{$\mathbf{Q}$} & \multirow[t]{2}{*}{ JC1 } & \multirow[t]{2}{*}{$\mathrm{JC}$ items [JCI] } & \multicolumn{5}{|c|}{ Frequency } & \multirow[t]{2}{*}{ Mean SD } \\
\hline & & & & 1 & 2 & 3 & 4 & 5 & \\
\hline 1 & 1 & $\mathrm{JC} 1$ & My job is pleasing to me & $\begin{array}{l}10 \\
3.33\end{array}$ & $\begin{array}{l}27 \\
9.00\end{array}$ & $\begin{array}{l}44 \\
14.67\end{array}$ & $\begin{array}{l}145 \\
48.33\end{array}$ & $\begin{array}{l}74 \\
24.67\end{array}$ & $\begin{array}{l}4.04 \\
0.92\end{array}$ \\
\hline 2 & 3 & $\mathrm{JC} 3$ & I am pleased with my colleagues & $\begin{array}{l}12 \\
4.00\end{array}$ & $\begin{array}{l}42 \\
14.00\end{array}$ & $\begin{array}{l}43 \\
14.33\end{array}$ & $\begin{array}{l}130 \\
43.33\end{array}$ & $\begin{array}{l}73 \\
24.33\end{array}$ & $\begin{array}{l}3.94 \\
01.07\end{array}$ \\
\hline 3 & 7 & $\mathrm{JC7}$ & $\begin{array}{l}\text { I am pleased with the opportunity to make an } \\
\text { impact in my department }\end{array}$ & $\begin{array}{l}10 \\
3.33\end{array}$ & $\begin{array}{l}33 \\
11.00\end{array}$ & $\begin{array}{l}86 \\
28.67\end{array}$ & $\begin{array}{l}132 \\
44.00\end{array}$ & $\begin{array}{l}39 \\
13.00\end{array}$ & $\begin{array}{l}3.73 \\
0.91\end{array}$ \\
\hline 4 & 6 & JC6 & My career progression is satisfactory & $\begin{array}{l}27 \\
9.00\end{array}$ & $\begin{array}{l}25 \\
8.33\end{array}$ & $\begin{array}{l}69 \\
23.00\end{array}$ & $\begin{array}{l}139 \\
46.33\end{array}$ & $\begin{array}{l}40 \\
13.33\end{array}$ & $\begin{array}{l}3.66 \\
1.11\end{array}$ \\
\hline 5 & 10 & $\mathrm{JC} 10$ & I am pleased with my department & $\begin{array}{l}13 \\
4.33\end{array}$ & $\begin{array}{l}49 \\
16.33\end{array}$ & $\begin{array}{l}62 \\
20.67\end{array}$ & $\begin{array}{l}142 \\
47.33\end{array}$ & $\begin{array}{l}34 \\
11.33\end{array}$ & $\begin{array}{l}3.64 \\
1.01\end{array}$ \\
\hline 6 & 5 & $\mathrm{JC} 5$ & I am pleased with my colleagues interactions & $\begin{array}{l}23 \\
7.67\end{array}$ & $\begin{array}{l}40 \\
13.33\end{array}$ & $\begin{array}{l}71 \\
23.67\end{array}$ & $\begin{array}{l}140 \\
46.67\end{array}$ & $\begin{array}{l}40 \\
13.33\end{array}$ & $\begin{array}{l}3.52 \\
1.06\end{array}$ \\
\hline 7 & 9 & JC9 & My department is performing well & $\begin{array}{l}22 \\
7.33\end{array}$ & $\begin{array}{l}64 \\
21.33\end{array}$ & $\begin{array}{l}56 \\
18.67\end{array}$ & $\begin{array}{l}127 \\
42.33\end{array}$ & $\begin{array}{l}31 \\
10.33\end{array}$ & $\begin{array}{l}3.42 \\
1.15\end{array}$ \\
\hline 8 & 2 & $\mathrm{JC} 2$ & The condition of service is satisfactory & $\begin{array}{l}31 \\
10.33\end{array}$ & $\begin{array}{l}69 \\
23.00\end{array}$ & $\begin{array}{l}58 \\
19.33\end{array}$ & $\begin{array}{l}108 \\
36.00\end{array}$ & $\begin{array}{l}43 \\
14.33\end{array}$ & $\begin{array}{l}3.32 \\
1.22\end{array}$ \\
\hline 9 & 8 & $\mathrm{JC} 8$ & $\begin{array}{l}\text { I am pleased with the welfare package for the } \\
\text { staff }\end{array}$ & $\begin{array}{l}28 \\
9.33\end{array}$ & $\begin{array}{l}78 \\
26.00\end{array}$ & $\begin{array}{l}67 \\
22.33\end{array}$ & $\begin{array}{l}96 \\
32.00\end{array}$ & $\begin{array}{l}31 \\
10.33\end{array}$ & $\begin{array}{l}3.20 \\
1.21\end{array}$ \\
\hline 10 & 4 & $\mathrm{JC} 4$ & $\begin{array}{l}\text { The rewarding system of the department is } \\
\text { satisfactory }\end{array}$ & $\begin{array}{l}48 \\
16.00\end{array}$ & $\begin{array}{l}75 \\
25.00\end{array}$ & $\begin{array}{l}83 \\
27.67\end{array}$ & $\begin{array}{l}63 \\
21.00\end{array}$ & $\begin{array}{l}31 \\
10.33\end{array}$ & $\begin{array}{l}2.92 \\
1.28\end{array}$ \\
\hline
\end{tabular}

Note: $\mathrm{JC}=$ Job Commitment; Figures below frequencies indicate percentages

considered. To test their correlations, item OCU-9 explains that the structures of the organization were formalized, item OCU-10 explains that the employees were governed by bureaucratic rules. Items of organisational culture OCU-9 and OCU-10 represented the hierarchical culture of the organisation. Item JS10 "I have too many assignments to complete at a time" was selected for job stress, while items JC-4 "The reward system is satisfactory" and JC-8 "I am pleased with the welfare packages for the staff" were selected for job commitment (Table 4).

The result of the correlation coefficient test explains the correlates between JS-10 and items JC-4 and JC- 8 the most dissatisfied items in Job commitment which was the main cause of stress. On Job stress, JS10 correlated significantly with the hierarchical culture of the organisation represented by OCU9 and OCU-10. Job commitment JC-4 and JC-8 also correlated significantly with item OCU-9 on culture. It may be concluded that there is a negative correlation between workplace stress and job commitment while job stress is positively correlated with hierarchical culture, while the job commitment has negative correlation with the hierarchical culture of the pharmaceutical industry.

\section{Discussion}

The observations of the study shows that the culture of the pharmaceutical companies in two districts i.e. Solan and Sirmour of Himachal Pradesh did not contribute significantly to the needs of the employees. The hierarchical culture of rules and regulations dominated the culture across pharmaceutical industries. The structure of hierarchy connotes that rewards and offer of responsibility are based on seniority and ranks. This system explained the reason for lack of commitment of the employees to their job which is also a potential source of stress. This also indicates that hierarchical culture is unsupportive and unsympathetic thus failed to promote innovative and visionary workers who can focus on change in the environment. These findings on hierarchical culture fall in line with the work of Lok and Crawford [16] that examined the three dimensions of culture such as innovative, supportive and bureaucratic in their study of the relationship between organisational culture, sub-culture and commitment and concluded that bureaucratic or hierarchical sub-culture had a negative influence and low levels of commitment respectively.

The failure of the organisational culture to contribute to the needs of the employees as found out by the study corroborates and is consistent with the work of Cameron and Nerina [5] on the positive relation between the 
Table 4. Correlation values between organisational culture, workplace stress and job commitment.

\begin{tabular}{|c|c|c|c|c|c|c|}
\hline Domain & Value of corelation & $\begin{array}{l}\text { Stress } \\
\text { JS10 }\end{array}$ & $\begin{array}{l}\text { Commitment } \\
\text { JC4 }\end{array}$ & $\begin{array}{l}\text { Commitment } \\
\text { JC8 }\end{array}$ & $\begin{array}{l}\text { Culture } \\
\text { DCU9 }\end{array}$ & $\begin{array}{l}\text { Culture } \\
\text { DCU10 }\end{array}$ \\
\hline Stres JS 10 & $\begin{array}{l}\text { Correlation co-efficient Sig [1-tailed] } \\
\mathrm{N}\end{array}$ & $\begin{array}{l}1.000 \\
300\end{array}$ & $\begin{array}{l}-0.470 \text { ** } \\
0.000 \\
300\end{array}$ & $\begin{array}{l}0.446 * * \\
0.000 \\
300\end{array}$ & $\begin{array}{l}0.215^{* *} * \\
0.000 \\
300\end{array}$ & $\begin{array}{l}0.135^{* *} \\
0.32 \\
300\end{array}$ \\
\hline $\begin{array}{l}\text { Commitment } \\
\text { JC4 }\end{array}$ & $\begin{array}{l}\text { Correlation co-efficient Sig[1-tailed] } \\
\mathrm{N}\end{array}$ & $\begin{array}{l}-0.470 \text { ** } \\
0.000 \\
300\end{array}$ & $\begin{array}{l}1.000 \\
300\end{array}$ & $\begin{array}{l}0.732 * * \\
0.000 \\
300\end{array}$ & $\begin{array}{l}0.310 * * \\
0.000 \\
300\end{array}$ & $\begin{array}{l}0.12 \\
0.376 \\
300\end{array}$ \\
\hline $\begin{array}{l}\text { Commitment } \\
\text { JC8 }\end{array}$ & $\begin{array}{l}\text { Correlation co-efficient Sig[1-tailed] } \\
\mathrm{N}\end{array}$ & $\begin{array}{l}-0.438^{* *} \\
0.000 \\
300\end{array}$ & $\begin{array}{l}0.732 * * \\
0.000 \\
300\end{array}$ & $\begin{array}{l}1.000 \\
300\end{array}$ & $\begin{array}{l}0.337^{* *} \\
0.000 \\
300\end{array}$ & $\begin{array}{l}0.563 \\
0.198 \\
300\end{array}$ \\
\hline $\begin{array}{l}\text { Culture } \\
\text { DCU9 }\end{array}$ & $\begin{array}{l}\text { Correlation co-efficient Sig[1-tailed] } \\
\mathrm{N}\end{array}$ & $\begin{array}{l}0.219 * * \\
0.000 \\
300\end{array}$ & $\begin{array}{l}-0.300 * * \\
0.000 \\
300\end{array}$ & $\begin{array}{l}-0.337 * * \\
0.000 \\
300\end{array}$ & $\begin{array}{l}1.000 \\
300\end{array}$ & $\begin{array}{l}0.490 * * \\
0.000 \\
300\end{array}$ \\
\hline $\begin{array}{l}\text { Culture } \\
\text { DCU10 }\end{array}$ & $\begin{array}{l}\text { Correlation co-efficient Sig[1-tailed] } \\
\mathrm{N}\end{array}$ & $\begin{array}{l}0.137 * \\
0.033 \\
300\end{array}$ & $\begin{array}{l}0.030 \\
0.377 \\
300\end{array}$ & $\begin{array}{l}0.063 \\
0.198 \\
300\end{array}$ & $\begin{array}{l}0.490 * * \\
0.000 \\
300\end{array}$ & $\begin{array}{l}1.000 \\
300\end{array}$ \\
\hline
\end{tabular}

**Correlation significant at 0.01 level [one-tailed]; *Correlation significant at 0.01 level [one-tailed].

employees subjective fit and the organisational values which concludes that individuals prefer an environment of work that possesses the same values as theirs and therefore appreciates their contributions and thus reward them accordingly Amos and Weathington [33].

The unconcerned approach of the organisation to the employee well-being resulting to low morale, decreased performance, high turnover and low job commitment also depends on individual differences and coping capabilities which is supplemented by the findings of Karasek [34], demand-control-decision latitude and the effects of individual psychological hardiness. This may be due to the fact that some employees may be more committed with high performance in such unsupportive environment that gives room for initiative and decisions over jobs, leading to a strong sense of purpose and commitment rather than a stress experience Sabrinazamzadeh and Abdekhodai [35].

Based on this, therefore, it is suggested that the pharmaceutical companies should adopt human relations cultural approach characterized by flexible internal focus, associated with broader human resource utilization that will promote trust, cohesion, participation through teamwork resulting in achieving employee morale and commitment. It is widely recognised that a supportive organisational culture is self-regulating, creative, promoting organisational ownership and satisfaction. The source of stress from findings of this study correlated significantly with the job commitment, indicating the unconcerned approach of the pharmaceutical industry to the well-being of managers resulting to low morale, decreased performance, high turnover and low job commitment.

\section{Conclusion}

To determine appropriate culture for all organisations, it is a very complex task to determine most appropriate culture for all organizations. This is because organizations have inherent structural and functional differentiation and inequalities in contexts in which the organisations operate. Values, beliefs and standards of behaviour differ across various organizations. Hence, all organisations should endeavour to evolve and develop a culture that is strong and supportive, prioritizes promotion of strong commitment and reduction of stress, and enhances organisational performance.

\section{References}

[1] Cohen, A. (2003) Multiple Commitments in the Workplace: An integrative Approach. Lawrence Eribaum Associates, London.

[2] Oke, A. (2008) Contextualising of Workplace Stress: The Experience of Bank Employees in Nigeria. Australian and New Zealand Academy of Management, Auckland, 2-5.

[3] Schein, E.H. (2009) The Corporate Culture Survival Guide. New and Revised Edition, Josey Bass, San Francisco.

[4] Williams, E.S., Konrad, T.R., Schekler, W.E. and Pathman, D.E. (2001) Understanding Physicians Intention to With- 
draw from the Practice: The Role of Job Satisfaction, Job Stress, Mental and Physical Health. Healthcare Management Review, 26, 7-19. http://dx.doi.org/10.1097/00004010-200101000-00002

[5] Brewer, E.W. and Clipboard, L.E. (2002) Burnout and Job Satisfaction among Student Support Services Personnel. Human Resource Development Charterly, 13, 169-186. http://dx.doi.org/10.1002/hrdq.1022

[6] Minor, J.B., Anger, K., Martz, E.A. and Ainato, N. (2009) Predictors of Job Stress among Staff in Jubenile Correlational Facilities. Criminal Justice and Behaviour, 36, 245-258.

[7] Ouchi, W. (1981) Theory Z. Addison-Wesley, Boston.

[8] Martins, N. (2002) Organisational Culture. In: Robbins, S.P. Oderdaah, A. and Roodt, G., Eds., Organisational Behaviour: Global and Southern African Perspectives, Pearson, Cape Town, 379-400.

[9] Levinson, M.H. (2004) Managing Organisational Stress through General Semantics. Et Cetera, 61, $245-254$.

[10] Cameron, K.S. and Quinn, R.E. (2006) Diagnosing and Changing Organisational Culture Based on Competing Values Framework. Josey Bass, San Francisco.

[11] Denison, D.R. and Mishra, A.K. (1995) Toward a Theory of Organizational Culture and Effectiveness. Organizational Science, 6, 204-223. http://dx.doi.org/10.1287/orsc.6.2.204

[12] Ogbonna, E. (2009) Organizational Culture and Commitment: A Study of an Indian Software Organization. The International Journal of Human Resource Management, 20, 654-675. http://dx.doi.org/10.1080/09585190802707433

[13] Bansal, A.K. and Monga, O.P. (2014) A Study on Job Performance of Managers in Pharmaceutical Industry in Himachal Pradesh. International Journal of Research in Computer Application \& Management, 4, 1-6.

[14] Robbins, S.P. (2001) Organizational Behaviour. Prentice Hall, Upper Saddle River.

[15] Flamholtz, E.J. (2001) Corporation Culture and the Bottom-Like. European Management Journal, 19, $268-275$. http://dx.doi.org/10.1016/S0263-2373(01)00023-8

[16] Lok, P. and Crawford, J. (1999) The Relationship between Commitment and Organizational Culture, Subculture, Leadership Style and Job Satisfaction in Organizational Change and Development. Leadership \& Organization Development Journal, 20, 365-377. http://dx.doi.org/10.1108/01437739910302524

[17] Monga, A., Verma, N. and Monga, O.P. (2015) A Study of Job Satisfaction of Employees of ICICI Bank in Himachal Pradesh. Human Resource Management Research, 5, 18-25.

[18] Bansal, A.K. and Monga, O.P. (2014) A Study on Impact of Socio-Demographic Variables on Job Satisfaction of Managers in Pharmaceutical Industry in Himachal Pradesh. Asian Academic Research Journal of Social Sciences and Humanities, 1, 123-139.

[19] Chang, S.I. (2008) Work Role Stressor and Turnover Intentions: A Study of IT Personnel in South Korea. Zeitschrift für Personalforschung, 22, 272-290.

[20] Daniels, K. (2004) Perceived Risk from Occupational Stress: A Survey of 15 European Countries. Occupational and Environmental Medicine, 61, 467-470. http://dx.doi.org/10.1136/oem.2003.009142

[21] Hart, P.M. and Cooper, C. (2001) Occupational Stress: Toward a More Integrated Framework. In: Anderson, N., Ones, D.S., Sinangil, H.K. and Viswesvaran, C., Eds., Handbook of Industrial, Work \& Organizational Psychology, Vol. 2, Sage Publications Ltd., Thousand Oaks, 93-144. http://dx.doi.org/10.4135/9781848608368.n6

[22] Kazue, D. and Stephen, T.T.T. (2011) Convergence and Divergence of Role Stress Experience of Locally Hired Japanese and Non-Japanese Host Country Staff: A Qualitative Study. The International Journal of Human Resource Management, 22, 218-231. http://dx.doi.org/10.1080/09585192.2011.538984

[23] Kanugo, R.P. (2006) Cross Culture and Business Practice: Are They Coterminous or Cross Verging? Cross Cultural Management: An International Journal, 13, 23-31.

[24] Elenkov, D. and Fileva, T. (2006) Anatomy of a Business Failure: Accepting the "Bad Luck" Explanation vs. Proactively Learning in International Business. Cross Cultural Management: An International Journal, 13, 133-141. http://dx.doi.org/10.1108/13527600610662311

[25] Matthew, J. and Ogbonna, E. (2009) Organizational Culture and Commitment: A Study of an Indian Software Organization. The International Journal of Human Resource Management, 20, 654-675. http://dx.doi.org/10.1080/09585190802707433

[26] Matthew, J. and Hawel, D. (1998) A Causal Model of the Antecedents of Organizational Commitment among Professionals and Non-Professionals. Journal of Vocational Behaviour, 34, 299-317.

[27] Lee, J.A. (2009) Organizational Justice: A Mediated Model from Individual Well-Being and Social Exchange Theory Perspectives.

[28] Olulana, B.S. (2015) The Correlates of Organizational Culture, Job Stress and Organizational Commitment. Asian Journal of Business and Management, 3, 155-164. 
[29] Zammuto, R.F. and Krakower, J.C. (1991) Quantitative and Qualitative Studies of Organizational Culture. Research in Organizational Change and Development, 5, 83-114.

[30] Quinn, R.E. and Spreitzer, G.M. (1991) The Psychometrics of the Competing Values Culture Instrument and an Analysis of the Impact of Organizational Culture on Quality of Life. In: Woodiman, R.W. and Pasmore, W.A., Eds., Research in Organizational Change and Development, Vol. 5, JAI Press, Greenwhich, 115-142.

[31] Quinn, R.E. (1988) Beyond Rational Management. Jossey-Bass, San Francisco.

[32] Meyer, J.P. and Allen, N.J.H. (1997) Commitment in the Workplace: Theory, Research Application. Sage, London.

[33] Amos, E.A. and Weathington, B.L. (2008) An Analysis of the Relation between Employee-Organization Value Congruence and Employee Attitudes. The Journal of Psychology, 142, 615-631. http://dx.doi.org/10.3200/JRLP.142.6.615-632

[34] Karasek, R. (1979) Job Demands, Jon Decision Latitude and Mental Strains: Implication for Job Redesign. Administrative Science Quarterly, 24, 285-306.

[35] Sabrinazamzadeh, R.I. and Abdekhodai, M.S. (2010) The Relationship between Consistency Feeling and Psychological Hardworking Coping Approaches. The Contemporary Psychology Quarterly. Contemporary Psychology, 5, 490-492. 